\title{
Physical-chemical, caloric and sensory characterization of light jambolan (Syzygium cumini Lamarck) jelly
}

\author{
Caracterização físico-química, calórica e sensorial de geleia de \\ jambolão light (Syzygium cumini Lamarck)
}

\author{
Ellen Silva LAGO-VANZELA ${ }^{1}$, Ginaldo Vieira dos SANTOS ${ }^{2}$, \\ Fernanda Arcaro de LIMA ${ }^{1}$, Eleni GOMES ${ }^{3}$, Roberto DA-SILVA ${ }^{4 *}$
}

\begin{abstract}
In Brazil, several little economically explored fruits have good potential as raw material for the agro-industry. This study aimed to produce and determine the physical-chemical and sensory characteristics of light jambolan jelly. This fruit has intense purple color, which gave the jellies - both standard and light - a quite attractive visual aspect. The light jellies exhibited similar physical-chemical characteristics to the ones developed through the conventional method and; with the proportion of sweeteners used, the caloric values of the formulations were reduced to the range of 41 to $53 \%$, attending the requirements of the Brazilian legislation for this type of product. The sensory profile obtained for the 4 light formulations developed, clearly showed the tasters' preference for the jelly elaborated with the association of cyclamate and saccharin. Thus, the results revealed good perspectives for the application of this fruit in the food industry.
\end{abstract}

Keywords: jambolan; light jelly; sweetener.

\section{Resumo}

No Brasil, muitas frutas, pouco exploradas economicamente, apresentam potencial como matéria-prima para a agroindústria. Este trabalho objetivou elaborar e determinar as características físico-químicas e sensoriais da geleia light de jambolão. Esta fruta tem uma coloração roxa intensa que conferiu às geleias, tanto padrão quanto light, aspecto visual bastante atrativo. As geleias light apresentaram características físico-químicas próximas daquelas desenvolvidas de forma convencional e, nas proporções de edulcorantes empregadas, os valores calóricos das formulações foram reduzidos na faixa de $41 \%$ a $53 \%$, enquadrando-se nas normas exigidas pela legislação brasileira para este tipo de produto. O perfil sensorial obtido para as 4 formulações light desenvolvidas evidenciou a preferência dos provadores pela geleia elaborada com a associação de ciclamato e sacarina. Assim, os resultados obtidos evidenciam boas perspectivas para a aplicação desta fruta na indústria de alimentos.

Palavras-chave: jambolão; geleia light; edulcorante.

\section{Introduction}

Recent researches in the food and nutrition sectors have called the attention of consumers towards the interest in fresh and processed foods that offer some additional benefits to health (ABDULLAH; CHENG, 2001; PASTORE, 2005). In order to meet these new standards of food demand, many native or introduced fruits, little explored economically, can be tested as raw material for domestic industrial use (PASTORE, 2005; LAGO; GOMES; DA-SILVA, 2006). Syzygium cumini is a fruit commonly known in Brazil as jambolan that, when ripe, presents intense purple color - very attractive for industrial processing. It is traditionally known in its native country (India) for its physiological and nutritional benefits (MORTON, 1987). Aqueous and ethanolic extracts extracted from jambolan seeds are frequently used in the treatment of diabetes mellitus. Some studies have shown that, when these extracts were added to the diet of diabetic animals, there was a glycemia level reduction (PRINCE; MENON; PARI, 1998; GROVER; VATS; RATHI, 2000; SHARMA et al., 2003) and, this therapeutic effect has been associated to some inorganic compounds (RAVI; SEKAR; SUBRAMANIAN, 2004). The juice from unripe fruits is used as raw-material in vinegar production and it is considered by the Indian popular medicine as stomach and diuretic medicine (BANERJEE; DASGUPTA; DE, 2005). Ripe fruits are used in the production of juices, nectars and jellies (BANERJEE; DASGUPTA; DE, 2005; MORTON, 1987). Recent studies have shown that the jambolan presents high anthocyanin content (LAGO; GOMES; DA-SILVA, 2006; TOBAL, 2007; VEIGAS et al., 2007), considered similar to the one found

Laboratório de Bioquímica e Microbiologia Aplicada, Universidade Estadual Paulista - UNESP, Rua Cristóvão Colombo, 2265, CEP 15054-000,

São José do Rio Preto, SP, Brasil

2 Departamento de Engenharia de Alimentos, Universidade Estadual Paulista - UNESP, Rua Cristóvão Colombo, 2265, CEP 15054-000,

São José do Rio Preto, SP, Brasil

${ }^{3}$ Departamento de Biologia, Universidade Estadual Paulista - UNESP, Rua Cristóvão Colombo, 2265, CEP 15054-000, São José do Rio Preto, SP, Brasil

${ }^{4}$ Departamento de Química e Ciências Ambientais, Universidade Estadual Paulista - UNESP, Rua Cristóvão Colombo, 2265, CEP 15054-000,

São José do Rio Preto, SP, Brasil, e-mail: dasilva@ibilce.unesp.br

${ }^{*}$ Corresponding author 
in blueberries, classified as a nutraceutic commodity of high commercial value (VEIGAS et al., 2007). Brito et al. (2007) observed that the main anthocyanins present in jambolan harvested in Brazil are the following: delphinidin, cyanidin, petunidin, peonidin and malvidin diglucoside, the first one being predominant. On the other hand, Veigas et al. (2007) reported that, after qualitative determination of anthocyanins present in jambolan harvested in India, the main anthocyanins are delphinidin, petunidin and, especially, malvidin-3-o-glucoside. Also, these authors observed that the anthocyanic extract from jambolan presents relatively high stability at high temperature and high antioxidant activity. Similar results were obtained by Hassimotto, Genovese and Lajolo (2005), Tobal (2008) and Faria et al. (2011) after studying Brazilian jambolan in natura, characterizing the fruit as an important source of bioactive compounds.

The ingestion of antioxidant rich foods presents a relevant role in the prevention of cardiovascular diseases and cancer (GERBER et al., 2002; KRIS-ETHERTON et al., 2002; SERAFINI et al., 2002), as well as neurodegerative diseases, including Parkinson's and Alzheimer's disease (DI-MATTEO; ESPOSITO, 2003).

Besides the presence of anthocyanins, jambolan contains tannins - phenolic compounds of high molecular weight that, as in cashew (Anacardium sp.) and green banana (Musa sp.), give the pulp an astringent taste. It is known that, in small proportions or in combination with other food compounds, astringency can contribute to a desirable taste, such as in wines produced from red grapes cultivar. In addition, when ingested in small amounts, the tannins naturally present in fruits may be beneficial to human health due to its anticarcinogenic activity and its antimutagenic effect (AGOSTINHO-COSTA; DA-SILVA, 2008).

In a study carried out in Brazil, it was noted that after jambolan jelly production, this astringency was masked and the product presented pleasant taste, characteristic of the fruit (LAGO; GOMES; DA-SILVA, 2006). Therefore, jambolan presents potential for being used as raw-material in the manufacture of food products (BARCIA; MEDINA; ZAMBIAZI, 2007; BARCIA et al., 2005; KHURDIYA; ROY, 1985; KANNAN; THIRUMARAN, 2004; LAGO; GOMES; DA-SILVA, 2006), being used as food additives (dyes) (TOBAL, 2007) and in pharmaceutical formulations (VEIGAS et al., 2007). Thus, taking into consideration the importance of developing light and diet sweets and jellies from new sources of raw-materials, this work had the purpose of elaborating light jelly from jambolan and evaluating its physical-chemical and sensory characteristics.

\section{Materials and methods}

\subsection{Raw-material and ingredients}

The fruits were picked ripe in São José do Rio Preto, in the northwest region of the State of São Paulo in January 2009 and were transported to the Biochemistry and Applied Microbiology Laboratory at the Institute of Biosciences, Language and Physical Sciences (IBILCE), UNESP - São Paulo State University, São José do Rio Preto campus; they were then selected, washed in running water, treated in a solution of sodium hypochlorite (200 ppm) (Isofar, Brazil) for 15 minutes, rinsed, conditioned in plastic sacks and kept under refrigeration $\left(5-7^{\circ} \mathrm{C}\right)$ until the beginning of the processing. For the elaboration of the jellies the following ingredients and addictives were used: sucrose (Cristal); glucose, citric acid, calcium chloride, sorbic acid, acesulfame-k, cyclamate, saccharin (Plury Química Ltda.); sucralose (Splenda) and three types of pectin (donated by CPKelco) - one with semi-rapid gelification (GENU Pectin Type 115, with metoxilation range between 66-70\%); one with rapid gelification (GENU Pectin Type 105, with metoxilation range between $70-76 \%$ ) and one specific for low sugar jellies with soluble solids of 45-60\% (GENU Pectin Type LM-101 LS, with metoxilation lower than 50\%).

\subsection{Processing of the jellies}

The fruits were separated from the seed with the aid of an stainless steel knife and homogenized with water in an industrial stainless steel blender with 2 L capacity (Tron), at 25,000 rpm velocity when empty, at a proportion of seedless fruit:water of 0.7:0.3. Separation of skin and pulp was carried out by using a $0.59 \mathrm{~mm}$ diameter sieve and pulp $\mathrm{pH}$ was adjusted to 3.4 by using acidulant citric acid.

Conventional jelly (control formulation): was manufactured according to Lago, Gomes and Da-Silva (2006) using a proportion of pulp:sugar of 0.6:0.4 (being the sugar in the proportion of sucrose:glucose of $0.8: 0.2)$ and $1 \%$ of pectin (in the proportion of type 105:type 115 of $0.7: 0.3, \mathrm{w} / \mathrm{w}$ ). This mixture underwent cooking in a $5 \mathrm{~L}$ capacity stainless steel pan, with continued manual agitation until the desired final soluble solids concentration was reached. The total soluble solids content was measured using a refractometer (Abbe Modelo 2 Waj, Biobrix). It should be emphasized that the choice for the pectins was based on the $\mathrm{pH}$ of the pulp, on the soluble solids content and, mainly, on the product potting temperature. It is known that, in artisanal processing scale, the long period of time spent in the potting step decreases jellies temperatures to values not recommended for Pectin GENU type 105, which is $85^{\circ} \mathrm{C}$, damaging the execution of this step of the process. Thus, a viable alternative is the use of pectins with slower gelification (SOLER, 1991), which is the case of Pectin GENU type 115. Despite the difference in the jellifying temperature between the tested products be small $\left(5^{\circ} \mathrm{C}\right)$, the metoxilation level of the pectins has a direct influence on functional properties such as solubility, jellifying capacity and conditions (SILVA, 2006). The association of these pectins probably provided enough time for the handling during the potting and cooling steps and, therefore, a jambolan jelly with better texture.

Light formulations: To define the formulations of sweeteners the following parameters were taken into consideration: the sweeteners stability in processing conditions (high acidity and temperature) and the synergistic effect of combinations of sweeteners described in the literature. It is known that different sweeteners present specific characteristics of intensity, persistence of the sweet taste and presence or not of residual taste. Therefore, some test formulations were initially elaborated and simplified tastings (bench scale tests) 
were carried out to establish formulations that resulted in products exhibiting taste and characteristics similar to the conventional product (CARDELLO; SILVA; DAMÁSIO, 2000). All formulations selected for chemical and sensory analysis took into consideration the average equivalent sweetness of the sweeteners and their maximum limits, as defined by the Brazilian legislation (BRASIL, 2008). We intend, in the near future, to carry out a study to determine the equivalent sweetness and the sweetening power of the best combination of sweeteners compared to sucrose, as well as evaluate the acceptance of this product at the concentration determined as ideal.

For the four light formulations, $1.5 \%$ of low metoxilation pectin and $60 \mathrm{mg}$ of calcium chloride were used to help gel formation. To keep sweetness at the same level, $30 \%$ of sugar was replaced for the combination of the sweeteners in the following proportions in weight: cyclamate:saccharin, 0.65:0.35 $\left(\mathrm{F}_{1}\right)$; sucralose:saccharin, 0.80:0.20 ( $\left.\mathrm{F}_{2}\right)$; acessulfame-k:cyclamate:saccharin, 0.40:0.40:0.20 $\left(\mathrm{F}_{3}\right)$ and, acessulfame-k:sucralose, 0.50:0.50 $\left(\mathrm{F}_{4}\right)$.

These jellies were also subjected to cooking in a $5 \mathrm{~L}$ capacity stainless steel pan, with continued manual agitation until the desired final soluble solids concentration was reached. The total soluble solids content was measured using a refractometer (Abbe Modelo 2 Waj, Biobrix). After that, $0.05 \%$ (p/p) of sorbic acid preservative was added only to the light formulation in order to control the growth of filamentous fungi and yeasts.

After this stage, all jellies were bottled, still hot, in $250 \mathrm{~g}$ glass pots, previously sterilized at $121^{\circ} \mathrm{C}$ for 15 minutes, closed with metal lids, immediately in cold water for 15 minutes and kept at room temperature.

\subsection{Physical-chemical determinations of jellies}

The jellies were analyzed regarding protein content, lipid, $\mathrm{pH}$, total soluble solids ( ${ }^{\circ} \mathrm{Brix}$ ), acidity (direct titration in citric acid) and moisture according to the methodologies established by Adolfo Lutz Institute (PREGNOLATTO; PREGNOLATTO, 1985). Total sugar, according to Dulbois et al. (1956); reducing sugars according to Miller (1958); and non-reducing sugars, through the difference between the last two; were determined. The results were evaluated by variance analysis (ANOVA) and the values that showed significant mean difference were complemented with Tukey's test, at probability $(\mathrm{p} \leq 0.05)$ level of 5\%, using the computer program ESTAT - version 2.0 (KRONKA; BANZATTO, 2004). From the content of energetic compounds, caloric content was calculated according to Franco (1989).

\subsection{Sensory analysis of the jellies}

The affective test for acceptability was carried out with potential fruit jelly consumers. In order to do so, the recruiting questionnaire presented in Chart 1 was given to a group of 160 individuals comprising undergraduate and graduate students, teachers and administration employees at São Paulo State University - UNESP, São José do Rio Preto campus. On the basis of the answers, individuals who presented interest and availability to participate in the tests and the habit to consume conventional and light products were selected. This study was submitted to and approved by the Ethics in Research Committee from UNESP/IBILCE (Report N 36/09 and CAAE - 0010.0.229.000-09) and the participants signed a Term of Consent according to Resolution 196/96, which contains the policies and regulations for researches involving human beings (FARIA; YOTSUYANAGI, 2008).

The tests occurred at the same time as the physical-chemical evaluations, at individual cabins in the Sensory Analysis Laboratory of the Food Engineering Department at UNESP. $20 \mathrm{~g}$ samples were served randomly to the panelists, in plastic recipients identified with 3 digit codes. The panelists were asked to indicate how much they liked/disliked the jellies based on the following attributes: appearance, color, odor, texture, taste and global evaluation, according to a 9 point hedonic scale $(1=$ disliked extremely; 2 = disliked very much; $3=$ disliked moderately; $4=$ disliked slightly; $5=$ neither liked nor disliked; $6=$ liked slightly; 7 = liked moderately; $8=$ liked very much; $9=$ liked extremely).

Chart 1. Questionnaire used to recruit panelists for the light jellies affective tests.

\begin{tabular}{|c|c|c|c|}
\hline \multicolumn{4}{|c|}{ Recruitment of jelly tasting panelists } \\
\hline \multicolumn{4}{|l|}{ Personal information } \\
\hline \multicolumn{4}{|l|}{ Name: } \\
\hline \multicolumn{4}{|l|}{ Telephone number: } \\
\hline 1) Age & 2) Sex & 3) Jelly consumption frequency & 4) Intake of light products \\
\hline ( ) up to 25 years old & ( ) female & ( ) consumes daily & ( ) consumes daily \\
\hline ( ) from 26 to 35 years old & ( ) male & ( ) consumes occasionally & ( ) consumes occasionally \\
\hline ( ) from 36 to 50 years old & & ( ) does not consume & ( ) does not consume \\
\hline ( ) more than 50 years old & & & \\
\hline
\end{tabular}


To avoid any influence on tasters due to fatigue or indifference on the evaluation of the last sample, the evaluation of the four light jelly formulations was carried out in two steps: in the first block, the $\mathrm{F}_{1}$ and $\mathrm{F}_{2}$ formulations were compared and in the second block, the $\mathrm{F}_{3}$ and $\mathrm{F}_{4}$ formulations were compared. To be certain that differences in the appearance between samples could not influence the panelists' answers, the evaluations of color and appearance attributes were carried out in white light while the other attributes assessments (odor, texture and taste) took place in red light. These attributes were chosen to be evaluated since they are part of first impression parameters, which have great influence on the consumption of food products (MORI, 1982). The results were evaluated by variance analysis (ANOVA) and the values that showed significant mean difference were complemented with Tukey's test, at probability ( $\mathrm{p} \leq 0.05$ ) level of $5 \%$, using the computer program ESTAT - version 2.0 (KRONKA; BANZATTO, 2004).

After that, the light jellies selected from previous sensory analysis $\left(\mathrm{F}_{1}\right.$ and $\left.\mathrm{F}_{4}\right)$ were evaluated through a preference affective test (paired comparison). The samples were presented to the panelists in white colored disposable recipients, coded with three random algorisms. After tasting, they were required to indicate the preferred sample. Each sample was made up of approximately $20 \mathrm{~g}$ of jelly, at room temperature, according to the recommendations of the International Organization for Standardization (ISO 5497, 1982) (FARIA; YOTSUYANAGI, 2008). The minimum number needed to establish preference of a sample over another was established by consulting the Table for Paired Comparison Test (FARIA; YOTSUYANAGI, 2008).

\section{Results and discussion}

\subsection{Physical-chemical analysis of jellies}

In the standard jelly obtained in this work, the total soluble solids content $\left(72^{\circ} \mathrm{Brix}\right)$ was superior to the one found by Barcia et al. (2005) and by Lago, Gomes and Da-Silva (2006) for jambolan jelly, which were 67 and $68^{\circ} \mathrm{Brix}$, respectively. This variation did not result in apparent damages to the jelly taste and texture and the value obtained was close to the one found for other jellies such as hibiscus $\left(73^{\circ} \mathrm{Brix}\right)$ (NACHTIGALL;
ZAMBIAZI, 2006). Thus, the product was used as a control sample for comparison with the light formulations. Light jellies presented lower total soluble solids contents than the one found for the standard jelly, which was expected due to the sugar reduction. Besides, there was a 41 to $53 \%$ reduction on total sugar content for the light jellies, which is a major component and practically defines the caloric value of jellies (Figure 1).

Table 1 shows that, independent of the light formulations, $\mathrm{pH}$ values did not present significant differences; however, they were a little higher than the value obtained for the standard jelly. When developing light jambolan jelly using only saccharin as sugar substitute, Barcia et al. (2005) reported similar behavior; however, the value was lower (3.38) than the ones found in this work (3.68-3.72). The light jellies, except for the formulation containing cyclamate and saccharin $\left(\mathrm{F}_{1}\right)$, presented acidity values slightly lower than the one found for the standard jelly. These results differ from the ones reported by Granada et al. (2005) and Mota (2007) which, after developing and chemically characterizing light pineapple and blackberry jellies, respectively, noted formulations (different combinations of sweeteners) with acidity values higher than the ones found for the control jelly (with sucrose). Alterations on the light formulations, as well as on standard jelly, did not have a great interference on the lipid and protein contents. The values found were above those reported for light pineapple jelly (GRANADA et al., 2005). As

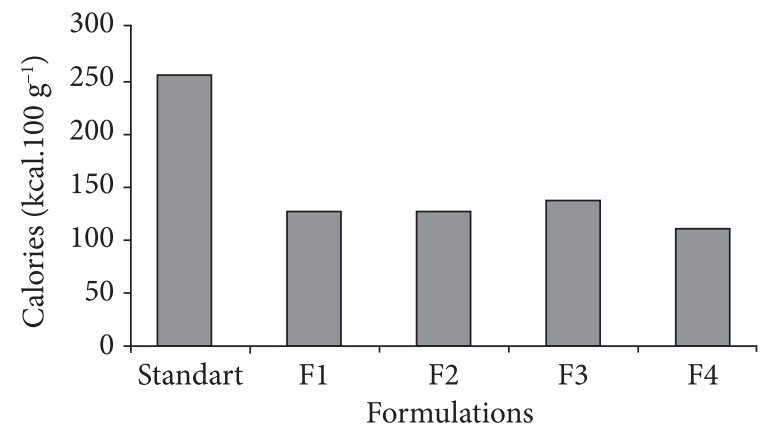

Figure 1. Reduction of the caloric value of the light jambolan jellies in comparison to standard jelly. (F1. cyclamate: saccharin; F2 - sucralose: saccharin; F3. acessulfame-k: cyclamate: saccharin; F4. acesulfame-k:sucralose).

Table 1. Physical-chemical determinations of standard and light jellies. *

\begin{tabular}{|c|c|c|c|c|c|}
\hline \multirow[t]{2}{*}{ Determinations } & \multicolumn{5}{|c|}{ Formulations } \\
\hline & Standard & F1 & $\mathrm{F} 2$ & F3 & F4 \\
\hline Moisture (\%) & $25.50 \pm 0.21^{\mathrm{a}}$ & $47.83 \pm 0.49^{\mathrm{b}}$ & $47.86 \pm 0.15^{\mathrm{b}}$ & $47.72 \pm 0.09^{\mathrm{b}}$ & $47.79 \pm 0.17^{\mathrm{b}}$ \\
\hline Protein (\%) & $0.54 \pm 0.01^{\mathrm{a}}$ & $0.57 \pm 0.00^{\mathrm{ab}}$ & $0.62 \pm 0.04^{\mathrm{b}}$ & $0.65 \pm 0.05^{\mathrm{b}}$ & $0.62 \pm 0.02^{\mathrm{b}}$ \\
\hline Lipids (\%) & $0.28 \pm 0.02^{\mathrm{a}}$ & $0.27 \pm 0.02^{\mathrm{a}}$ & $0.23 \pm 0.01^{\mathrm{a}}$ & $0.26 \pm 0.01^{\mathrm{a}}$ & $0.25 \pm 0.01^{\mathrm{a}}$ \\
\hline Total sugars (\% glucose) & $68.0 \pm 2.0^{\mathrm{a}}$ & $37.0 \pm 2.0^{\mathrm{b}}$ & $37.0 \pm 2.0^{\mathrm{b}}$ & $32.0 \pm 1.0^{c}$ & $36.0 \pm 1.0^{\mathrm{b}}$ \\
\hline Reducing sugars (\% glucose) & $29.0 \pm 1.0^{\mathrm{a}}$ & $17.0 \pm 0.0^{\mathrm{b}}$ & $14.0 \pm 1.0^{\mathrm{c}}$ & $15.0 \pm 0.0^{\mathrm{bc}}$ & $17.0 \pm 0.0^{\mathrm{b}}$ \\
\hline Non-reducing sugars (\% sucrose) & $39.0 \pm 0.7^{\mathrm{a}}$ & $19.0 \pm 1.0^{\mathrm{b}}$ & $21.0 \pm 1.4^{c}$ & $17.0 \pm 1.1^{\mathrm{b}}$ & $19.0 \pm 1.0^{\mathrm{b}}$ \\
\hline Total soluble solids ( ${ }^{\circ}$ Brix) & $72.0 \pm 0.00^{\mathrm{a}}$ & $51.0 \pm 0.00^{\mathrm{b}}$ & $52.0 \pm 0.00^{\mathrm{b}}$ & $55.5 \pm 0.00^{c}$ & $50.0 \pm 0.00^{b}$ \\
\hline Acidity (\%) (in citric acid) & $1.09 \pm 0.03^{\mathrm{a}}$ & $1.09 \pm 0.01^{\mathrm{a}}$ & $0.98 \pm 0.00^{c}$ & $1.02 \pm 0.01^{\mathrm{b}}$ & $0.99 \pm 0.01^{\circ}$ \\
\hline $\mathrm{pH}$ & $3.56 \pm 0.02^{b}$ & $3.70 \pm 0.01^{\mathrm{a}}$ & $3.70 \pm 0.03^{a}$ & $3.72 \pm 0.02^{\mathrm{a}}$ & $3.68 \pm 0.01^{\mathrm{a}}$ \\
\hline
\end{tabular}

*Values followed by the same letter on the same row do not differ significantly by the Tukey's test ( $<<0.05)$. F1 - sweeteners cyclamate:saccharin in the proportion of 0.65:0.35; F2 - sucralose:saccharin in the proportion of 0.80:0.20; F3 - acesulfame-k:ciclamate:saccharin in the proportion of 0.40:0.40:0.20; F4 - acesulfame-k:sucralose in the proportion of 0.50:0.50. 
expected, the standard jelly differed from the light formulations by presenting lower moisture content caused by the higher sugar concentration. Due to the higher water activity, light jellies are more susceptible to microbial contamination (coliforms, filamentous fungi and/or yeasts). Thus, it is necessary to carry out microbiological analysis during storage in order to determine the period in which the product exhibits adequate sanitary conditions.

It was observed that the light jellies exhibited caloric reduction of approximately $50 \%$, which is superior to what was previously planned (theoretical) for the formulations. For jellies of different fruits, a reduction between 30 and $50 \%$ on the sugar content is common when compared to the conventional formulation (GRANADA et al., 2005; MENDONÇA et al., 2000; MOTA, 2007; TEIXEIRA; SOUZA; ZAMBIAZI, 2001). Examples are light strawberry, peach, plum and pineapple jellies (TEIXEIRA; SOUZA; ZAMBIAZI, 2001), as well as apple jelly (MENDONÇA et al., 2000) and pineapple (GRANADA et al., 2005), which exhibited 21 to $37 \%$ reduction on the total sugar content.

\subsection{Sensory analysis of the jellies}

Among the 160 individuals who answered the recruiting questionnaire, $68 \%$ were female and $32 \%$ male. Out of these, 105 individuals were pre-selected by the team and only fifty were required for the analysis, with $50 \%$ from the total of women and $6 \%$ from the total of men within the age range of 26-35 (Figure 2). In spite of the percentage of women being significantly higher, it is known that the sexual category does not interfere in the acuity of sensory analysis. This age range is preferred since the individuals normally present well defined consuming habits, good health and financial condition. The consumption frequency reported by the recruited population showed that percentages higher than $70 \%$ from the total of women and men occasionally ate jellies or light products (Figure 3), being the recruitment of panelists satisfactory for the objectives of the research.

After the light jellies acceptability tests, it was possible to note that, in Block A, the use of the cyclamate and saccharin mixture resulted in a product $\left(\mathrm{F}_{1}\right)$ with pleasant sensory characteristics, and the grades of the analyzed attributes were significantly better than the ones for the jelly made with sucralose and saccharin $\left(\mathrm{F}_{2}\right)$. Taccharin presents low price when compared to other sweeteners; high sweetening power; high stability throughout a wide range of temperature and $\mathrm{pH}$; low hygroscopicity; easy incorporation to liquid or dry mixtures (PINHEIRO et al., 2005); easy solubility in hot or cold water; and it is not metabolized by the human organism. This versatility of saccharin allows its use in many food products due to its stability towards storage and heating, and also because it blends well with other sweeteners and it can be successfully incorporated to both liquid and dry mixtures (NABORS; GELARDI, 1986). In spite of presenting residual bitter taste in aqueous solution, this bitterness can be masked or minimized when mixed with other sweeteners (HIGGINBOTHAM, 1983).

One of the sweeteners used in association with saccharin is cyclamate, which presents excellent taste quality, exceptional storage stability, as well as high solubility in water and stability at a wide range of $\mathrm{pH} 2.0-10.0$ and at high temperatures (WELLS et al., 1989). The combined use of cyclamate and saccharin to provide the sweetness in diet and light food products is very common in Brazil due to the synergism it offers. These positive effects were also evidenced in this study for jambolan jelly.

Sucralose is also used in combination with saccharin. This sweetener exhibits excellent chemical and biological stability, which makes its use possible in any type of product, including foods with low $\mathrm{pH}$ and subject to thermal treatment (NABORS, 2002). Besides, it presents advantages in comparison to other sweeteners because its taste is very similar to sucrose and, when combined with saccharin, it masks the metallic residual taste which is distinctive in saccharin (PINHEIRO et al., 2005). In jambolan jelly, this characteristic was not impressive since the interaction between the sweeteners and compounds of the jelly did not result in preferential acceptance by the panelists.

In block $\mathrm{B}$, the combinations of sweeteners tested were acesulfame-k:cyclamate:saccharin and acesulfame-k:sucralose. Acesulfame-k exhibits a sweetness profile similar to glucose: rapidly perceptive sweetness, with low decrease, but not persistent, nevertheless, with a slightly superior lasting sweetness when compared to sucrose. Besides, it is highly

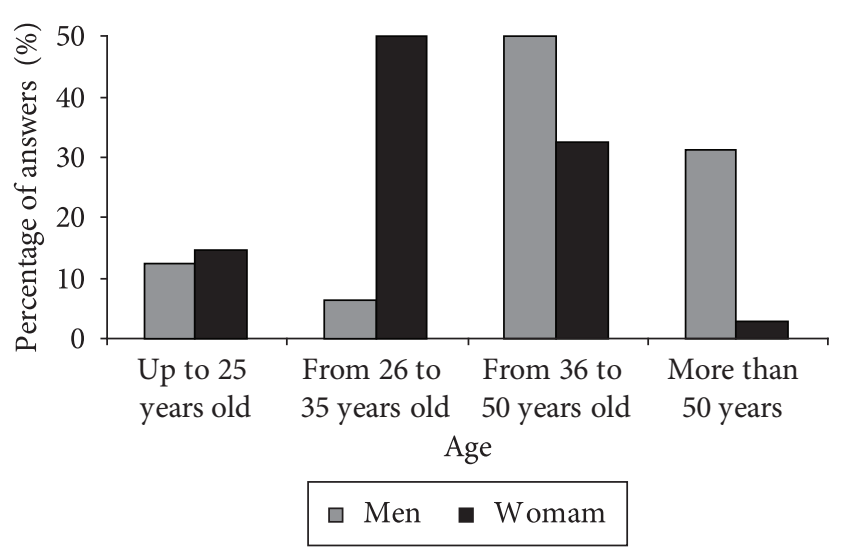

Figure 2. Age distribution of the panelists required for the analysis of light jambolan jelly.

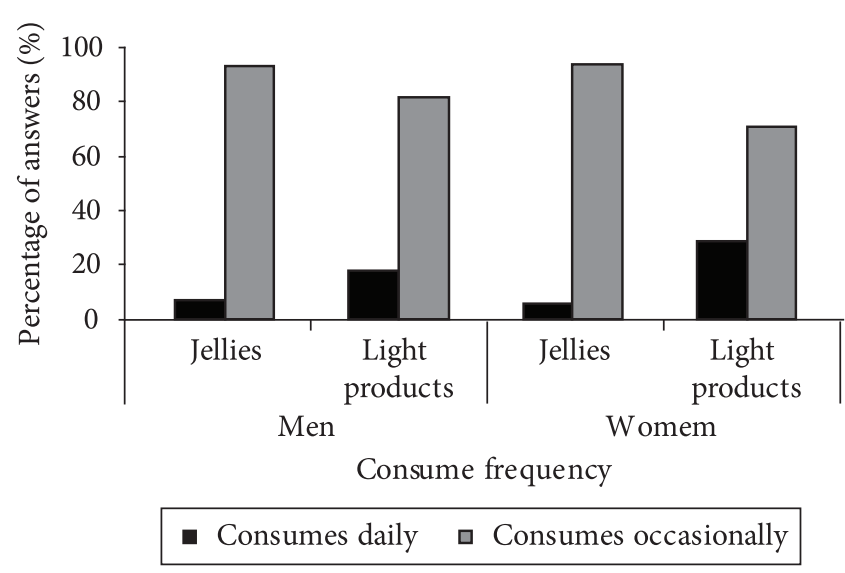

Figure 3. The consumption frequency reported by the recruited population. 
Table 2 - Sensory characteristics of jambolan jellies. ${ }^{\star}$

\begin{tabular}{|c|c|c|c|c|c|c|}
\hline \multirow[t]{3}{*}{ Attributes } & \multicolumn{6}{|c|}{ Formulations } \\
\hline & \multicolumn{3}{|c|}{ Block A } & \multicolumn{3}{|c|}{ Block B } \\
\hline & F1 & F2 & LSD & F3 & $\mathrm{F} 4$ & LSD \\
\hline Appearance & $6,68 \pm 1,42^{\mathrm{a}}$ & $7,32 \pm 1,58^{\mathrm{b}}$ & 0,03 & $6,56 \pm 1,47^{\mathrm{a}}$ & $6,88 \pm 1,42^{\mathrm{a}}$ & 0,02 \\
\hline Color & $7,52 \pm 1,20^{\mathrm{a}}$ & $7,96 \pm 1,16^{\mathrm{b}}$ & 0,02 & $7,32 \pm 1,39^{\mathrm{a}}$ & $7,40 \pm 1,40^{\mathrm{a}}$ & 0,01 \\
\hline Odor & $5,44 \pm 2,11^{\mathrm{a}}$ & $6,24 \pm 2,25^{\mathrm{b}}$ & 0,03 & $5,24 \pm 1,96^{a}$ & $5,52 \pm 2,01^{a}$ & 0,02 \\
\hline Texture & $6,04 \pm 1,58^{\mathrm{a}}$ & $6,68 \pm 1,58^{\mathrm{b}}$ & 0,05 & $5,56 \pm 1,72^{\mathrm{a}}$ & $6,12 \pm 1,62^{b}$ & 0,04 \\
\hline Taste & $6,04 \pm 1,91^{\mathrm{a}}$ & $6,64 \pm 1,79^{\mathrm{b}}$ & 0,06 & $5,72 \pm 2,09^{\mathrm{a}}$ & $5,86 \pm 1,81^{\mathrm{a}}$ & 0,04 \\
\hline Global evaluation & $6,44 \pm 1,40^{\mathrm{a}}$ & $6,84 \pm 1,56^{\mathrm{b}}$ & 0,03 & $6,08 \pm 1,41^{\mathrm{a}}$ & $6,52 \pm 1,54^{\mathrm{b}}$ & 0,03 \\
\hline
\end{tabular}

${ }^{*}$ Values followed by the same letter on the same line, for each block, do not differ significantly by the Tukey's test $(\mathrm{p}<0,05)$. F1 - cyclamate: saccharin; F2 - sucralose: saccharin; F3 - acesulfame-k: cyclamate: saccharin; F4 - acesulfame-k:sucralose); LSD. Least Significant Difference of Tukey's test.

stable at $\mathrm{pH}$ variation in foods and beverages (3 to 7$)$, it can be rapidly diluted in water and it is not affected by thermal processes (NABORS, 2002). In spite of being able to be used as the only sweetening system, acesulfame-k presents synergistic properties which make it very interesting when associated with other sweeteners, probably due do the sum of the time-intensity profiles of each sweetener (LIPINSKI, 1991).

These combinations present many positive characteristics, such as stability at low values of $\mathrm{pH}$ and high temperatures, zero calories, maximization of sweetening power and improvement on the sensory profile of the products (MENDONÇA; ZAMBIAZI; GRANADA, 2001). Table 2 shows that formulations $\mathrm{F}_{3}$ and $\mathrm{F}_{4}$ presented significant differences only concerning the texture attribute. However, the statistical analysis of the scores for global evaluation showed that the jelly made with sucralose and acesulfame-k presented better acceptance by the panelists. According to the comments of the panelists, expressed on the sensory evaluation form, a slight bitter taste was noted on the formulation using acesulfame-k:cyclamate:saccharin, probably due to the presence of acesulfame-k. On the other hand, when the product was elaborated with sucralose and acesulfame-k, the panelists observed an improvement on the product sweet taste.

Based on these results, we chose to continue the studies with formulations $F_{1}$ and $F_{2}$, which were evaluated by affective test of preference. The results revealed that 35 out of 55 panelists preferred the jelly made with cyclamate and saccharin. The minimum number of trials to establish preference for a sample over another, for this case, was 33 . Therefore, it can be concluded that the jelly made with cyclamate and saccharin was significantly more preferred than the one made with acessulfame- $\mathrm{k}$ and sucralose, at the $5 \%$ level of significance.

There is a great concern regarding the safety of ingesting the cyclamate/saccharin mixture and investigations concerning their effects on the human beings are gaining importance (MEDEIROS, 2007). So far, the results from many studies carried out to verify the toxicity of these sweeteners indicate few physiopathological effects even when ingesting high doses (FATIBELLO-FILHO et al., 1996; MEDEIROS, 2007; YAN et al., 2005). In spite of the fact that these sweeteners recently had their limits for maximum use in food products reduced by the National Agency of Sanitary Vigilance (ANVISA) (BRASIL, 2008), respecting the established limits, they can be used by the food industries and be normally ingested.

\section{Conclusions}

Light jambolan jelly exhibited physical-chemical characteristics which were in agreement with what is demanded by the Brazilian legislation. The jelly formulated with cyclamate and saccharin presented better sensory characteristics when compared to the other formulations and, consequently, better acceptance among the panelists. The results obtained encourage new studies in order to improve the formulation and also the use of this product as a new alternative for the agro industry.

\section{Acknowledgements}

The authors are grateful to CAPES for the student's grant and to $\mathrm{CNPq}$ for the productivity scholarship.

\section{References}

ABDULLAH, A.; CHENG, T. C. Optimization of reduced calorie tropical mixed fruits jam. Food Quality and Preference, v. 12, n. 1, p. 63-68, 2001. http://dx.doi.org/10.1016/S0950-3293(00)00030-6

AGOSTINHO-COSTA, T. S.; DA-SILVA, D. B. Jambolão: a cor da saúde. Agrosoft Brasil. Disponível em: <http://www.agrosoft.org. br/pdf.php/?node=28814>. Acesso em: 10 mar. 2008.

BANERJEE, A.; DASGUPTA, N.; DE, B. In vitro study of antioxidant activity of Syzygium cumini fruit. Food Chemistry, v. 90, n. 4, p. 727-733, 2005. http://dx.doi.org/10.1016/j.foodchem.2004.04.033

BARCIA, M.; MEDINA, A.; ZAMBIAZI, R. Características sensoriais de geléia light de jambolão. In: CONGRESSO DE INICIAÇÃO CIENTÍFICA, 16., 2007, Pelotas. Anais... Pelotas: Universidade Federal de Pelotas, 2007. p. 106-113. Disponível em: <http://www. ufpel.tche.br/cic/2007/cd/pdf/CA/CA_00245.pdf >. Acesso em: 13 dez. 2007.

BARCIA, M. T. et al. Elaboração de geléia light a partir de polpa de jambolão. In: SIMPÓSIO LATINO-AMERICANO DE CIÊNCIA EM ALIMENTOS - SLACA, 6., 2005, Campinas. Proceedings... Campinas: Unicamp, 2005. v. 1, p. 1-1.

BRASIL. Resolução RDC n 18 , de 24 de março de 2008. Regulamento técnico que autoriza o uso de aditivos edulcorantes em alimentos, com seus respectivos limites máximos. Diário Oficial da República Federativa do Brasil, Brasília, DF, 25 mar. 2008. Disponível em: <http://e-legis.anvisa.gov.br/leisref/public/showAct. php?id=30216\&word=\#>. Acesso em: abr. 2008.

BRITO, E. S. et al. Anthocyanins Present in Selected Tropical Fruits: Acerola, Jambolão, Jussara, and Guajiru. Journal of Agriculture and Food Chemistry, v. 55, n. 23, p. 9389-9394, 2007. 
CARDELLO, H. M. A. B.; SILVA, M. A. A. P.; DAMÁSIO, M. H. Análise descritiva quantitativa de edulcorantes em diferentes concentrações. Ciência e Tecnologia de Alimentos, v. 20, n. 3, p. 318-328, 2000. http://dx.doi.org/10.1590/S0101-20612000000300008

DI-MATTEO, V.; ESPOSITO, E. Biochemical and therapeutic effects of antioxidants in the treatment of Alzheimer's disease, Parkinson's disease, and amyotrophic lateral sclerosis. Current Drug Targets CNS and Neurological Disorder, v. 2, n. 2, p. 95-107, 2003.

DULBOIS, N. et al. Colorimetria method for determination of sugars and related substances. Nature, v. 28, n. 3, p. 350-356, 1956.

FARIA, A. F. et al. Identification of bioactive compounds from jambolão (Syzygium cumini) and antioxidant capacity evaluation in different pH conditions. Food Chemistry, v. 126, n. 4, p. 1571-1578, 2011.

FARIA, E. V.; YOTSUYANAGI, K. Técnicas de análise sensorial. 2. ed. Campinas: ITAL, 2008. 120 p.

FATIBELLO-FILHO, O. et al. Adoçantes artificiais. Química Nova, v. 19 , n. 3, p. 248-257, 1996.

FRANCO, G. Tabela de composição química de alimentos. 8. ed. Rio de Janeiro: Livraria Atheneu, 1989. 230 p.

GERBER, M. et al. Food and cancer: State of the art about the protective effect of fruits and vegetables. Bulletin du Cancer, v. 89, n. 3, p. 293-312, 2002.

GRANADA, G. G. et al. Caracterização física, química, microbiológica e sensorial de geléias light de abacaxi. Ciência e Tecnologia de Alimentos, v. 25, n. 4, p. 629-635, 2005. http://dx.doi.org/10.1590/ S0101-20612005000400002

GROVER, J. K.; VATS, V.; RATHI, S. S. Anti-hyperglycemic effect of Eugenia jambolana and Tinospora cordifolia in experimental diabetes and their effects on key metabolic enzymes involved in carbohydrate metabolism. Journal of Ethnopharmacology, v. 73, n. 3, p. 461-470, 2000. http://dx.doi.org/10.1016/S0378-8741(00)00319-6

HASsimotTo, N. M. A.; GENOVESE, M. I.; LAJOLO, F. M. Antioxidant activity of dietary fruits, vegetables, and commercial frozen fruit pulps. Journal of Agricultural and Food Chemistry, v. 53, n. 8, p. 2928-2935, 2005. http://dx.doi.org/10.1021/jf047894h

HIGGINBOTHAM, J. D. Recent developments in non-nutritive sweeteners. In: GREMBY,T. H.; PARKER, K. J.; LINDLEY, M. G. Developments in sweeteners-2. London: Applied Science. Publ., 1983. p. 119-55.

KANNAN, S.; THIRUMARAN, S. Studies on the storage life of jamun (Syzygium cumini Rom) fruit products. Journal of Food Science and Technology, v. 41, n. 2, p. 186-188, 2004.

KHURDIYA, D. S.; ROY, S. K. Processing of jamun (Syzygium cumini Linn) fruit into a ready to serve beverage. Journal of Food Science and Technology, v. 22, n. 1, p. 27-30, 1985.

KRIS-ETHERTON, P. M. et al. Bioactive compounds in foods: Their role in the prevention of cardiovascular disease and cancer. American Journal of Medicine, v. 113, n. 8, p. 71-88, 2002. http:// dx.doi.org/10.1016/S0002-9343(01)00995-0

KRONKA, S. N.; BANZATTO, D. A. Estatística aplicada à engenharia de alimentos. Jaboticabal: UNESP, FCAV, 2004.

LAGO, E. S.; GOMES, E.; DA-SILVA, R. Produção de geléia de jambolão (Syzygium cumini Lamarck): processamento, parâmetro físico-químicos e avaliação sensorial. Ciência e Tecnologia de Alimentos, v. 26, n. 4, p. 847-852, 2006. http://dx.doi.org/10.1590/ S0101-20612006000400021

LIPINSKI, G. W. V. R. Acesulfame-K. In: NABORS, L. O. B.; GELARDI, R. C. Alternative sweeteners. New York: Marcel Dekker, Inc., 1991. p. 11-38.
MEDEIROS, R. A. Determinação voltamétrica de aspartame e ciclamato de sódio em produtos dietéticos empregando um eletrôdo de diamante dopado com bromo. 2007. Dissertação (Mestrado em Quimica)-Universidade Federal de São Carlos, São Carlos, 2007.

MENDONÇA, C. et al. Sucralose em geléias de maçã. In: CONGRESSO BRASILEIRO DE CIÊNCIA E TECNOLOGIA DE ALIMENTOS, 17., 2000, Fortaleza. Anais... Fortaleza: Sociedade Brasileira de Ciência e Tecnologia de Alimentos, 2000. v. 2, p. 5.194.

MENDONÇA, C. R.; ZAMBIAZI, R.; GRANADA, G. G. Partial substitution of sugars by the low-calorie sweetener sucralose in peach compote. Journal of Food Science, v. 66, n. 8, p. 1195-1200, 2001.

MILLER, G. L. Use of dinitrosalicylic acid reagent for determination of reducing sugar. Analytical Chemistry, v. 31, n. 3, p. 426-428, 1958. http://dx.doi.org/10.1021/ac60147a030

MORI, E. E. M. Métodos sensoriais e físicos para avaliação de alimentos e bebidas: princípios de aplicação. Campinas: ITAL, 1982. cap. 1: Noções gerais sobre qualidade.

MORTON, J. Jambolan. In: MORTON, J. F. Fruits of warm climates. Miami, 1987. p. 375-78. Disponível em: <http://www.hort.purdue. edu/newcrop/morton/jambolan_ars.html>. Acesso em: nov. 2005.

MOTA, R. V. Características químicas e aceitabilidade de geléias de amora-preta de baixo teor de sólidos solúveis. Brazilian Journal of Food Technololy, v. 10, n. 2, p. 116-121, 2007.

NABORS, L. O. B. Sweet choices: sugar replacements for foods and beverages. Food Technology, v. 56, n. 7, p. 28-35, 2002.

NABORS, L. B.; GELARDI, R. C. Alternatives sweeteners. New York: Marcel Dekker, 1986. 335 p.

NACHTIGALL, A. M.; ZAMBIAZI, R. C. Geléias de hibisco com reduzido valor calórico: características sensoriais. Boletim do Centro de Pesquisa e Processamento de Alimentos, v. 24, n. 1, p. 47-58, 2006.

PASTORE, G. M. Alimentos funcionais: a inovação industrial na área de alimentos. 2005 Disponível em: <http://www.comciencia.br/ repostagens/2005/09/13.shtml >. Acesso em: mar. 2008.

PINHEIRO, M. V. S. et al. The effect of different sweeteners in low-calorie yogurts - a review. International Journal of Dairy Techmology, v. 58, n. 4, 2005. http://dx.doi.org/10.1111/j.14710307.2005.00228.x

PREGNOLATTO, W.; PREGNOLATTO, N. P. (Coords.). Normas analíticas do Instituto Adolfo Lutz: métodos químicos e físicos para análise de alimentos. 2. ed. São Paulo: Instituto Adolfo Lutz, 1985. p. 25-27, 49-50, 232-233.

PRINCE, P. S. M.; MENON, V. P.; PARI, L. Hypoglycaemic activity of Syzygium cumini seeds: effect on lipid peroxidation in alloxan diabetic rats. Journal of Ethnopharmacology, v. 61, n. 1, p. 1-7, 1998. http://dx.doi.org/10.1016/S0378-8741(98)00002-6

RAVI, K.; SEKAR, D. S.; SUBRAMANIAN, S. Hypoglycemic activity of inorganic constituents in Eugenia jambolana seed on streptozotocininduced diabetes in rats. Biological Trace Element Research, v. 99, n. 1-3, p. 145-155, 2004.

SERAFINI, M. et al. Total antioxidant potential of fruit and vegetables and risk of gastric cancer. Gastroenterology, v. 123, n. 4, p. 985-991, 2002. http://dx.doi.org/10.1053/gast.2002.35957

SHARMA, S. B. et al. Hypoglycaemic and hypolipidemic effect of ethanolic extracts of seeds of Eugenia jambolana in alloxan-induced diabetic rabbits. Journal of Ethnopharmacology, v. 85, n. 2-3, p. 201-206, 2003. http://dx.doi.org/10.1016/S0378-8741(02)00366-5 
SILVA, A. C. A. Serviço Brasileiro Resposta Técnica - SBRT. Porto Alegre: Senai-RS, 2006.

SOLER, M. P. Industrialização de Geléias: Processamento Industrial. Campinas: ITAL, 1991. (Manual Técnico, n. 7).

TEIXEIRA, A. M.; SOUZA, N. L.; ZAMBIAZI, R. Elaboração de geléias light. In: SIMPÓSIO DE CIÊNCIA DE ALIMENTOS, 2001, Florianópolis. Proceedings... Florianópolis: Sociedade Brasileira de Ciência e Tecnologia de Alimentos, Regional Santa Catarina, 2001. p. QB.31.

TOBAL, T. M. Uso do Syzygium cumini (L.) skells como antioxidantes em suco de laranja e avaliação de sua interferência sensorial. 2008. 63 f. Dissertação (Mestrado em Engenharia e Ciência dos
Alimentos)-Universidade Estadual de São Paulo, São José do Rio Preto, 2008.

VEIGAS, J. M. et al. Chemical nature, stability and bioefficacies of anthocyanins from fruit peel of Syzygium cumini Skeels. Food Chemistry, v. 105, n. 2, p. 619-627, 2007. http://dx.doi. org/10.1016/j.foodchem.2007.04.022

YAN, Z. et al. Separation and simultaneous determination of four artificial sweeteners in food beverages by ion chromatography. Journal of Chromatography A, v. 1085, n. 1, p. 143-146, 2005. http://dx.doi.org/10.1016/j.chroma.2004.12.042

WELLS, A. G. The use of intense sweeteners in soft drinks. In: GREMBY, T. H. Progress in sweeteners. New York: Elsevier Apllies Science, 1989. p. 121-142. 